Lukács Liza* - Túry Ferenc

\title{
A PROCEDURÁLIS EMLÉKEZET SZEREPE A TESTKÉP ZAVARAIBAN
}

\begin{abstract}
Az evészavarok egyik vezetô betegségfenntartó tényezóje a betegek torzult, diszfunkcionális kogníciója. Ezen belül is kiemelendók a táplálékfelvételi viselkedés zavaraival és a testélménnyel kapcsolatban lévő, a zavarok létrejöttében kulcsszerepet játszó kognitív disztorziók, melyek az információfeldolgozási folyamatokon belül elsősorban a perceptuális élményfeldolgozást érintik és evészavaros betegeknél a testkép speciális zavarában mutatkoznak meg. A kognitív információfeldolgozást a sémák irányítják, amelyekben a selfról való komplex tudás szerveződik. A sémák procedurális ismeretanyagot is hordoznak, úgy mint motoros készségeket, szokásokat, szabályokat, célképzeteket, döntéshozatali stratégiákat. Ezek alapján felmerül, hogy az evészavarokra jellemzó viselkedéses rutincselekvések, mint például a diétázás, falásroham, önhánytatás a testkép sémáján belül procedurális élményanyagként kódolódhat és a munkamemóriában automatikusan a többi explicit tudással és emlékkel együtt aktiválódik. Elméleti áttekintésünkben ezeknek a prekognitív folyamatoknak keressük a helyét és szerepét az evészavaros betegekre jellemző kognitív információfeldolgozási jellegzetességek kialakításában.
\end{abstract}

Kulcsszavak: evészavarok, kognitív információfeldolgozás, sémák, implicit és explicit memória, kognitív viselkedésterápiák, prekognitív diszfunkciók

Az evészavarok egyik vezetô betegségfenntartó tényezôje a betegek torzult, diszfunkcionális kogníciója. Széles körú kutatási adatok utalnak arra, hogy az evészavarban szenvedó betegek jellegzetes kognitív stílusát az emlékezeti, képzeleti, figyelmi, gondolkodási, döntéshozatali folyamatok diszfunkcionális múködése jellemzi (áttekintés: Lukács és Túry 2003).

Ezen belül is kiemelendók az evési viselkedés zavaraival és a testélménnyel kapcsolatban lévő, a zavarok létrejöttében kulcsszerepet játszó kognitív disztorziók, melyek az információfeldolgozási folyamatokon belül elsôsorban a perceptuális élményfeldolgozást érintik, és evészavaros betegeknél a testkép speciális zavarában mutatkoznak meg.

Az evészavarok a legmakacsabb pszichiátriai kórképek között számon tartott, dinamikusan növekvő morbiditással jellemezhetô krónikus beteg-

\footnotetext{
* Levelező szerzó:

Lukács Liza, Semmelweis Egyetem, Magatartástudományi Intézet

1089 Budapest, Nagyvárad tér 4.

E-mail: lalita3@freemail.hu
} 
ségek. A kognitív viselkedésterápiák (a továbbiakban KVT) napjainkban az egyik leggyümölcsözóbb terápiás eljárást képviselik az evészavarok területén, hatékonyságuk mégis mindössze 40-50\%-ra tehetố (György 1993). A KVT célja a kognitív restrukturálás. Az evészavarokkal kapcsolatban végzett hatékonyságvizsgálatok során felmerült, hogy KVT-ben a kognitív restrukturálás elsősorban az evési szokásokra, a testsúllyal kapcsolatos kognitív torzulásokra, diszfunkcionális attitúdökre vonatkozik; a testképre, az alakkal, testsúllyal kapcsolatos aggodalmaskodást ugyanakkor elsósorban viselkedésterápiás módszerekkel igyekeznek korrigálni (Túry és Szabó 2000). A testképzavarral járó kórképek kezelésében elterjedtek a testorientált terápiák - táncterápia, mozgásterápia, videokonfrontáció, masszázs stb. (áttekintés: Vandereycken és mtsai 1987; Probst 1997) -, amelyekkel nagyobb testi tudatosság érhetô el, korrigálhatók az érzelem kifejezésének és felismerésének, valamint a metakommunikációnak a zavarai is; segítik az énkép reálissá válását, majd a test elfogadását, a saját test élvezetének megtanulását.

Ugyanakkor felmerül, hogy evészavarokban a kórlefolyás során bizonyos készségszintre került diszfunkcionális viselkedések és hiedelmek, az evészavarokra jellemzó viselkedéses rutincselekvések - mint például a diétázás, falásroham, önhánytatás - funkcionálisan önállósodnak, a testkép sémáján belül procedurális élményanyagként kódolódnak és a munkamemóriában automatikusan a többi explicit tudással és emlékkel együtt aktiválódnak (Stein és Hedger 1997).

Az evészavarok kognitív hátterét vizsgáló eljárások közül leggyakrabban önkitöltó kérdớives módszereket használnak a kutatók, ezek közül is kiemelendő elterjedtsége miatt az Evészavar Kérdóív (Eating Disorder Inventory, EDI), az Evési Attitúdök Tesztje (Eating Attitudes Test, EAT40) és az Anorexiás Kogníciók Kérdôíve (Anorectic Cognitions Questionnaire, ACQ). Ezeknek közös jellemzóje, hogy ki vannak téve az önbeszámolás torzításának - mint minden kérdôíves eljárás (Hermans és mtsai 1998). A kérdóíves eljárások számos pszichiátriai zavarnál kiválóan alkalmasak a tünetek milyenségének, gyakoriságának rögzítésére, a betegség felismerésére, a pszichopatológiai háttér feltérképezésére, azonban az evészavarral és a testképzavarral járó szindrómák esetén felmerül, hogy az önbeszámoló torzítása találkozik az e kórformákra markánsan jellemzó elutasítás és torzítás patológiás, a zavart fémjelző kognitív és emocionális jegyeivel. Power (1991) hangsúlyozza, hogy a kérdőíves vizsgáló eljárások a humán kognitív információfeldolgozásnak pusztán egy viszonylag szúk területét fedik le (tudatos verbalizációval kifejezhető élmények), míg a verbális tudatosságon kívül eső folyamatokat és prekognitív reprezentációkat figyelmen kívül hagyják. 
Az utóbbi közel 10 évben az evési- és testképzavarokkal járó szindrómák (l. testi diszfóriás személyekkel végzett kutatások) egyre népszerúbb vizsgáló eszközei a kognitív információfeldolgozás jellegzetességeinek vizsgálatára szolgáló Stroop teszt (Williams és mtsai 1988), valamint a priming feladatok (pl. töredékkiegészítés) és a memória feladatok. Ezeket sikeresen módosították annak érdekében, hogy a teljes kognitív struktúrát és az információfeldolgozás alacsonyabb tudatossági szintjeit is vizsgálni tudják elsósorban emocionális zavarral járó, valamint egyéb pszichiátriai megbetegedéseknél.

A testükkel elégedetlen személyekkel végzett kutatások eredményei kapcsolódási pontot jelentenek az evészavarban szenvedó és az izomdiszmorfiás (muscle dysmorphia, MD) betegek pszichopatológiája között (Pope és mtsai 1993; Pope és Katz 1994; Whitehead 1994; Pope és Hudson 1996; Gyenis és Túry 1996/97; Túry és Gyenis 1997; Pope és mtsai 1997; Phillips és mtsai 1997; Connan 1998; Olivardia és mtsai 2000; Pope és mtsai 2000; Kovács és Túry 2001).

\section{A HUMÁN MEGISMERÉS ÉPÍTŐKÖVEI: A SÉMÁK}

A kognitív információfeldolgozást a sémák irányítják, amelyekben a selfról való komplex tudás szervezódik; ez specifikus viselkedéses és emocionális jegyekben fejeződik ki (Markus 1977). A testképpel kapcsolatban ilyen emocionális vonás az evészavarokban a testtel való elégedetlenség érzése, a testsúly miatt fellépó szorongás és aggódás; míg egyik kiemelt viselkedéses összetevóje a karcsúságra törekvés (Stein és Hedger 1997).

A self sémák szerkezeti felépítésüket tekintve olyan hierarchikus struktúrák, amelyeknek a csúcsán az absztrakt, konceptuális vagy szemantikus tudás helyezkedik el, míg alapját a helyzet-specifikus epizodikus emlékezeti elemek alkotják (Kihlstrom és mtsai 1988; Taylor és Crocker 1981). Tartalmi jellemzóit tekintve a self a tudatos és tudattalan énreprezentációk egyedileg szervezett rendszere. Az implicit memória tartalmai azok a készséggé szerveződött emlékek, illetve perceptuális emlékek, amelyek nem kerültek mélyebb feldolgozási szintre; ide tartoznak az automatizált kognitív múveletek is.

Ezáltal az énsémák procedurális ismeretanyagot is hordoznak, úgy mint érzékszervi-mozgásos emlékeket, motoros készségeket, szokásokat, szabályokat, célképzeteket, döntéshozatali stratégiákat (Cantor és Kihlstrom 1987).

A selfsémák a memória elemei, explicit és implicit/procedurális ismeretanyagot is tartalmaznak, ugyanakkor az adott szituációs ingerek ál- 
tal elóhívott, éppen múködó, az információfeldolgozás erôterében lévố énfogalom („,working self concept") csak bizonyos, helyzetspecifikus vonásait tartalmazza a selfnek (Markus és Wurf 1987). Az implicit memória elemei (célképzetek, döntéshozatali stratégiák) nem tudatosak, így általában periferiálisak, a háttérból irányítják az információfeldolgozás folyamatát, automatikus rutincselekvések, érzelmi megnyilvánulások vagy járulékos emocionális állapotok (szorongás, depresszió) formájában manifesztálódnak. A testképzavarral társuló kórképek esetén felmerül, hogy az emocionális distresszt, szorongást indukáló élethelyzetek és azok a környezeti helyszínek, melyekhez a negatív érzelmek a kórlefolyás során kondicionálódtak, elóhívhatnak olyan énrészeket, amelyekhez tudattalanul a procedurális memóriában diszfunkcionális gondolatok, hiedelmek, automatizálódott rutincselekvések kapcsolódnak, meghatározva a kórkép további jellegzetességeiként számon tartott tüneteket (purgálás, falásroham, intenzív, kényszeres testedzés).

Az evészavarokra jellemző járulékos érzelmi állapotot (depresszió, hipománia, szorongás) az implicit memóriában rejtve maradt élményanyag indukálja. Ugyanakkor a KVT módszerével dolgozó terapeuta a kiváltó gondolat, helyzet (karcsúságideál, a testsúlyhoz, testalakhoz való viszonyulás, illetve annak realitásvizsgálata) átsrukturálására helyezi a hangsúlyt (György 1993).

Az énfogalmak tehát aktiválódásukkal hozzáférhetôvé válnak az explicit memóriában, amelyek további tartalmakat vonzanak az implicit memóriából.

Az énsémák megváltoztatásával kapcsolatban lényeges elkülöníteni azt a két lehetséges esetet, amikor új elem adódik az énfogalomhoz, illetve, amikor a már adott struktúrában történik szerkezeti változás (Markus és Wurf 1987). A KVT ez utóbbira helyezi a hangsúlyt, holott tudvalévő, hogy az evészavaros betegek coping, érzelemfelismerési, önismereti, önkontroll és kommunikációs készségei erósen hiányosak, tehát újabb, a beteg számára ismeretlen készségek elsajátítása is nélkülözhetetlen, amely egyben a relapszus-prevenciónak is része lehet.

A testsúly vonatkozású énsémák szisztematikus információfeldolgozási hibákat idéznek eló, amelyek a figyelem patológiás szelekciós mechanizmusában, a látszatkorreláció és a megerôsító hipotézis ellenơrzés jelenségében nyilvánul meg evészavaros betegeknél. A kognitív információfeldolgozás sémaalapú múködésének kiemelkedô szerepe van a tünetek hosszú távú fennmaradásában és automatikus aktiválódásában egyaránt (Hermans és mtsai 1998). 


\section{EGYETLEN, ÖSSZETETT MENTÁLIS PILLANAT: AZ EPIZÓD}

Az emlék epizodikus formában tárolódik a memóriában (Tulving 1983). Az epizód az élményszerú emlékezet alapegysége, amely egy olyan pszichológiai pillanatnak tekinthetó, amely nem csak perceptuális, de mentális elrendeződésben, ennek kontextusában tartalmazza az adott eseményt. A mentális érintkezés magyarázza Tulving értelmezésében, hogy mi minden kerül egyetlen epizódba, amely késóbb, akárcsak részleges elófordulásakor, az élmény ismerôsségének érzetét keltheti és az explicit élményanyag aktiválódásához vezet. Az epizód egyaránt tartalmazza a külső (észlelési) és belsó (érzelmek, gondolatok, hangulat) környezetét is. Ezeknek az epizódoknak az egységbe rendeződésével jön létre az élményszerú emlék, amely az explicit memória része. A kognitív információfeldolgozás mentális koordinált aktivitásként való felfogása is ezt támasztja alá.

\section{A TÖMEGKOMMUNIKÁCIÓ SZEREPE \\ A TESTKÉP ZAVARAIBAN: AZ IMPLICIT INDUKCIÓ EGYIK TIPIKUS FORMÁJA}

Evészavaros betegeknél gyakran megfigyelhetô, hogy vannak olyan tipikus, emocionális distresszt kiváltó helyek és helyzetek, amelyek anorexiás betegeknél erôsítik a korlátozó diétát, vagy a hiperaktív reakciók ingerei, míg bulimiás betegeknél a falásrohamok triggereként szolgálnak. Az ilyen szituációk megteremtésében kiemelt szerepet kapnak a médiumok, illetve az általuk közvetített szépségideál. A humán megismerés alapvetó jellemzóje, hogy az egyének a szituációknak az őket másoktól megkülönböztetô aspektusaira koncentrálnak (Markus és Wurf 1987). Miután napjainkban a tömegkommunikáció eredményeképpen a nók naponta kénytelenek szembesülni az extrém mértékben karcsú, fiatal modellekkel, kultúránkban túl sok az ellentétes „test-inger”. Sok nőnél ez stresszt, szorongást, depressziót, szégyenérzetet, bizonytalanságot, az önbecsülés csökkenését okozza, és a saját testükkel kapcsolatos elégedetlenséghez vezet (Stice és mtsai 1994).

\section{REJTETT, A KÓRLEFOLYÁS SORÁN KIALAKULÓ SCRIPTEK EVÉSZAVAROKBAN}

A célelérés stratégiái közül több - scriptek formájában - procedurális élményanyagként kódolódik, illetve reprezentálódik (Markus és Wurf 1987). A deklaratív/explicit és a procedurális/implicit tudásanyag közötti kap- 
csolatok döntóek a kognitív struktúra kialakításában és múködésében, a self és a viselkedés viszonylatában. A self sémák és a viselkedéses forgatókönyvek (scriptek) közötti kapcsolat jól összeforrt, együtt és automatikusan fejlódnek és aktiválódnak adott körülményeknek megfelelően, vagyis a self még a nem tudatos önszabályozás során is involválódik.

Evészavaros betegeknél ilyen scriptszerú, viselkedéses forgatókönyvként fogható fel a falásroham, valamint az utána bekövetkezó, a gyomortelítettség által fellépó stressz és szorongás indukálta purgálás, a laxatívumok átmeneti vagy rendszeres használata is. Hasonló ehhez bulimiás betegeknél az evési orgiák rituálészerú kivitelezése, anorexiásoknál az étel felaprítása vagy a body builderek evészavarának egyik jellemzô vonásaként az étel összetevőinek aprólékos kiválasztása, megtervezése és naponta szigorúan meghatározott időpontokban, idóközökben való elfogyasztása. Ha azonban bármi megzavarja a napi rutint, azt az érintett személyek erôteljes szorongással élik meg (Gruber és Pope 2000). Többé-kevésbé minden testképzavarral járó szindrómára, amelyben a test torzult észlelése a testtömeget, illetve az izom-zsír százalékos arányát érinti, jellemzô a napi rendszeres - sokszor túlzásba vitt - testedzés viselkedéses forgatókönyve. A viselkedésterápiák egyik jellemzó módszere az evési napló vezettetése a beteggel. Tulajdonképpen ez is tekinthetô egy adekvát a patológiás szokások forgatókönyve helyett kínált - scriptnek, amely idóvel automatikussá válik. Ez a kaotikus evési szokásokkal rendelkező bulimiások, illetve az éhség- és telítettségérzettel kapcsolatos interocepciójukban erôsen torzult anorexiások evési szokásait hivatott normalizálni. Az éhség és gyomortelítettség regulációja proprioceptív módon, implicit emlékként stabilizálja a scriptet.

Különösen anorexia nervosában megfigyelt jellegzetesség, hogy a betegségre jellemző diszfunkcionális hiedelmek a kórlefolyás során funkcionálisan önállósodnak. Ebben a folyamatban kiemelt szerepet kapnak a testkép sémáján belüli procedurális élményanyagként kódolódó környezeti és mentális jellemzók, melyek egyrészt fenntartják a percepció és az interocepció torzulását, másrészt kiváltják a testalak „ideálissá” formálásának - sok esetben patológiás - viselkedéses reakcióit (purgálás, testedzés, laxativumok vagy anabolikus szteroidok abúzusa).

Az evészavarok tüneti megjelenését alapvetóen meghatározó viselkedéses forgatókönyvek nyilvánvalóvá teszik az evészavarok kapcsolatát a kényszerbetegséggel. A fentiekben említett, az ételhez, evéshez fúződő rituális viszony mellett az evészavarosok perfekcionista, teljesítményorientált személyisége is kényszeres vonás (Túry és Szabó 2000); amely karakterisztikum jó „táptalajt” biztosít a patológiás scriptekkel tarkított 
viselkedésnek. A scriptek rituálészerú kivitelezése feszültségcsökkenést okoz, ami a kényszertünetek célja.

\title{
A KOGNITÍV INFORMÁCIÓFELDOLGOZÁS EGYÉNI JELLEGZETESSÉGEI: A STRUKTÚRA, A SZERVEZÓDÉS SZEREPE
}

\begin{abstract}
A KVT kiemelt hiányossága, hogy az egyéni különbségekre nem ad kelló magyarázatot. Az énsémák szervezódésének egyéni jellegzetességei ugyanakkor kritikus horgonypontjai lehetnek a tünetek megjelenésének, súlyosságának, a terápiás prognózis tekintetében. Showers és Larson (1999) vizsgálatukban evészavaros és nem evészavaros, de a fizikai megjelenés tekintetében negatív önértékelésú személyeket az énstruktúra szervezódésének tekintetében hasonlítottak össze. Elóbbiekre jellemzó volt, hogy nem integráltan, hanem olyan merev kategóriákba szervezetten kezelik a testi megjelenéssel kapcsolatos negatív információt, amelyek számos asszociációval rendelkeznek az Én egyéb - a fizikai megjelenéstól független - aspektusaira vonatkozóan is.
\end{abstract}

\section{ZÁRÓ GONDOLATOK}

Az implicit memóriából származó élményanyag szerepe, feldolgozási módja, illetve annak hatása a kognitív információfeldolgozásra nem követhetó nyomon a KVT jelenlegi módszereivel. Feltételezhetó, hogy az evészavarokra jellemzó relapszusveszély, illetve még inkább a tünetváltások mögött az implicit/procedurális élmény- és ismeretanyag terápiás negligálása húzódik meg.

Gyakorlati szempontból lényeges annak továbbgondolása, hogy az implicit/procedurális memóriában tárolt, az evészavarok elórehaladott stádiumaiban automatizálódott "prekognitív diszfunkciók” milyen hatással vannak a terápiás prognózisra.

További munkáinkban egy - a fentieket integráló - új, egészségpszichológiai kiindulópontú, rendszerszemléleti megközelítést képviselő kognitív modell kidolgozására teszünk kísérletet. 


\section{Irodalom}

Cantor, N., Kihlstrom, J. (1987): Personality and Social Intelligence. Englewood Cliffs, New Jersey: Prentice-Hall.

Connan, F. (1998): Machismo nervosa: an ominous variant of bulimia nervosa. Eur. Eating Dis. Rev. 6: 154-159.

Gruber, A. J., Pope, H. G. (2000): Psychiatric and medical effects of anabolic-androgenic steroid use in women. Psychother. Psychosom. 69: 19-26.

Gyenis M., Túry F. (1996/97): Az anabolikus szteroid abusus pszichiátriai vonatkozásairól a férfiak speciális testképzavara kapcsán. Appendix 1(3)-2(1): 35-39.

György S. (1993): Az evészavarok kognitív-viselkedésterápiás megközelítése. In: Riskó Á. (szerk.): Étkezési zavarok. Magyar Pszichiátriai Társaság, Budapest, 37-56.

Hermans, D., Pieters, G., Eelen, P. (1998): Implicit and explicit memory for shape, body weight, and food-related words in patients with anorexia nervosa and nondieting controls. J. Abnorm. Psychol. 107: 193-202.

Kihlstrom, J., Cantor, N., Albright, J. et al. (1988): Information processing and the study of the self. Advances in Experimental Social Psychology 21: 145-178.

Kovács Sz., Túry F. (2001): Az inverz anorexia megjelenése testépítók között. Mentálhigiéné és Pszichoszomatika 3 (3): 41-44.

Lukács L., Túry F. (2003): Az evészavarban szenvedók kognitív stílusa. Pszichoterápia 12: 94-101.

Markus, H. (1977): Self-schemata and processing information about the self. J. Personal Psychology 35: 63-79.

Markus, H., Wurf, E. (1987): The dynamic self-concept: a social psychological perspective. Ann. Rev. Psychol. 38: 299-337.

Markus, H., Hamill, R., Sentis, K. P. (1987): Thinking fat: self-schemas for body weight and the processing of weight relevant information. J. Applied Social Psychology 17: 5071.

Olivardia, R., Pope, H. G., Hudson, J. I. (2000): Muscle dysmorphia in male weightlifters: a case-control study. Am. J. Psychiatry 157: 1291-1296.

Phillips, K. A., O'Sullivan, R. L., Pope, H. G. Jr. (1997): Muscle dysmorphia. J. Clin. Psychiatry 58: 361.

Pope, H. G., Hudson, J. I. (1996): Anorexia nervosa and "reverse anorexia". NEDO Newsletter 30 (1): 1-2.

Pope, H. G., Katz, D. L., Hudson, J. I. (1993): Anorexia nervosa and "reverse anorexia" among 108 male bodybuilders. Compr. Psychiatry 34: 406-409.

Pope, H. G., Katz, D. L. (1994): Psychiatric and medical effects of anabolic-androgenic steroids: a controlled study of 160 athletes. Arch. Gen. Psychiatry 51: 375-382.

Pope, H. G. Jr., Gruber, A. J., Choi, P. et al. (1997): Muscle dysmorphia: an underrecognized form of body dysmorphic disorder. Psychosomatics 38: 548-557.

Pope, H. G., Gruber, A. J., Mangweth, B. et al. (2000): Body image perception among men in three countries. Am. J. Psychiatry 17: 1297-1301.

Power, M. J. (1991): Cognitive science and behavioural psychotherapy: where behaviour was, there shall cognition be? Behavioural Psychotherapy 19: 20-41.

Probst, M. (1997): Body Experience in Eating Disorder Patients. University Center Sint Jozef, Kortenberg. 
Showers, C. J., Larson, B. E. (1999): Looking at body image: the organization of self-knowledge about physical appearance and its relation to disordered eating. J. Personality 67: 659-700.

Stein, K. F., Hedger, K. M. (1997): Body weight and shape self-cognitions, emotional distress, and disordered eating in middle adolescent girls. Arch. Psychiatric Nursing 5: 264-275.

Stice, E., Schupak-Neuberg, E., Shaw, H. E. et al. (1994): Relation of media exposure to eating disorder-symptomatology: an examination of mediating mechanisms. J. Abnorm. Psychol. 103: 836-840.

Taylor, S. E., Crocker, T. (1981): Schematic bases of social information processing. In: Higgins, E. T., Herman, C. P., Zanna, M. P. (eds): Social cognition. The Ontario Symposium. Lawrence Erlbaum, Hillsdale, New Jersey, 39-88.

Tulving, E. (1983): Elements of Episodic Memory. Oxford University Press, New York.

Túry F., Gyenis M. (1997): Inverz anorexia nervosa: a férfiak speciális testképzavara. Psychiatria Hungarica 12: 589-594.

Túry F., Szabó P. (2000): A táplálkozási magatartás zavarai: az anorexia nervosa és a bulimia nervosa. Medicina, Budapest.

Vandereycken, W., Depreitere, L., Probst, M. (1987): Body-oriented therapy for anorexia nervosa patients. Am. J. Psychotherapy 41: 252-259.

Whitehead, L. (1994): Machismo nervosa: a new type of eating disorder in men. International Cognitive Therapy Newsletter 8: 2-3.

Williams, J., Watts, F., MacLeod, C. et al. (1988): Cognitive Psychology and Emotional Disorders. Wiley, Chichester.

\section{LUKÁCS, LIZA - TÚRY, FERENC \\ THE ROLE OF PROCEDURAL MEMORY IN TROUBLE OF BODY PICTURE}

The present theoretical overview discusses the general areas of cognitive functioning (the cognitive information processing, the theory of constructive perception, the role of schemata) especially to procedural memory. In addition to strategies for evaluating and drawing inferences about the self, behavioural routines such as dieting, bingeing, and purging may also be encoded within the body image schema as procedural knowledge and enhanced each time the schema is activated in working memory. Self-schemas are conceptualized as hierarchically organized structures with abstract, conceptual, or semantic knowledge at the top and context-specific episodic memories nested below. Self-schemas also include procedural knowledge like action-based memories in the form of motoric skills, habits, rules, and strategies for making judgments, drewing inferences, and accomplishing goals relevant to the domain. Present therapeutical methods cannot handle all these aspects of eating and body-dysmorphic disorders. The present paper discusses the role of precognitive processes in the development of characteristic information processing of eating disordered patients.

Keywords: eating disorders, cognitive information processing, self-schemas, implicit and explicit memory, cognitive behaviour therapies, precognitive dysfunctions 
